\title{
GROWTH AND DEVELOPMENT OF GOMPHRENA CELOSIOIDES MART UNDER SCREEN HOUSE CONDITIONS IN ILORIN, SOUTHERN GUINEA SAVANNA ZONE OF NIGERIA
}

"Takim, F. O., Olawoyin, O. K. and Olanrewaju, W. A.

Department of Agronomy, Faculty of Agriculture,University of llorin, PMB 1515, Ilorin, Nigeria.

*Corresponding Author: felixtakim@yahoo.co.uk

\begin{abstract}
The pattern of growth of Gomphrena celosioides Mart (Amaranthaceae), a weed in mown grass and lawn commonly used in southern Nigeria for treatment of skin infections and as abortifacient was evaluated in Ilorin (Lat. $8^{\circ} 29^{\prime} \mathrm{N}$ \& $8^{\circ} 30^{\prime} \mathrm{N}$; Long. 40 30'E \& $4^{\circ} 32^{\prime} \mathrm{E}$ ), southern Guinea savanna of Nigeria between 2010 and 2012. Seedlings and soil samples to a depth of $15 \mathrm{~cm}$ were collected from different locations and enumerated for 15 weeks. G. celosioides seedling had a prolific growth rate, producing many leaves, sparsely branching and excessive flowers within a short period after emergence. The estimated seeds of $G$. celosioides in soil seedbank were about $885 \mathrm{seeds} / \mathrm{m}^{2}$. The growing shoot increased in length as a function of plant age with a mean absolute growth rate of $0.13 \mathrm{~g} \mathrm{plant}^{-1} \mathrm{day}^{-1}$, mean $R G R$ of $0.07 \mathrm{~g} \mathrm{~g}^{-1} \mathrm{day}^{-1}$. This result will be valuable in aiding the prediction of $\mathrm{G}$. celosioides infestations in agricultural fields and provide a valuable input in timing of its control.
\end{abstract}

KeyWords: Weed biology, plant growth, seedbank, Gomphrena celosioides Mart,

\section{INTRODUCTION}

Knowledge of weed biology is essential for the development of economic and environmentally acceptable weed management systems (Bhowmik, 1997). To establish weed control strategies it is important to recognize the natural strategies of weeds infesting field crops. An annual weed occupies an important position in the agro ecosystem as a source of food for invertebrates, higher trophic groups, as well as having an intrinsic biodiversity value (Marshall et. al., 2003). Gomphrena celosioides Mart belongs to the family Amaranthaceae, it is an annual or short-lived perennial weed species, first discovered at Queensland in 1930, which has now spread throughout the old world tropics (Myers et al., 2000). It grows along roadsides, river banks, rail way and on fallow land, occasionally invades pastures. It is well distributed in South America, Asia, East and West Africa. Its presence in Ghana and Nigeria is recently recorded (Onocha et al., 2005).

It is a common and often troublesome weed of crops in the tropics and subtropics. Holm et al. (1979) classified it as "serious" in Taiwan and Thailand and "common" in Australia, India, Zimbabwe and South Africa. Wells et al. (1986) classified it as "competitive" and describe it as "replacing vegetation" in southern Africa. In Brazil, it is described as a damaging weed which is very common in dry land crops and plantations (Suzane et al., 2010). Gomphrena celosioides Mart is used in the treatment of several disease and abortifacient in South America. It is seldomly eaten by livestock. It is not known to be eaten by goats and it is toxic to horses when eaten in excess over extended periods (Fank-de-Carvallo et al.,2005). 
In Nigeria, it is use in ethnomedical practice for treatment of various skin diseases, worms' infections and infectious diseases (Onocha et al., 2005).

Several studies have been conducted to examine the medicinal potential of $G$. celosioides Mart. Oladele and Daodu (1988) studied the stem anatomical indices and recommended it as a revegetation plant in a desertified area while Onocha et al. (2005) reported on the phytochemical and biological activities of the plant extracts. It has been reported that weed distribution is determined by growth patterns (Van Gessel et al., 1998). Analysis of plant growth can be determined by different measurements and calculations. Dry matter and leaf area have been identified as important factors for analysis of plant growth (Radosevich et al., 1997; Horak and Laughlin, 2000). Little or no information is available on the growth pattern of $G$. celosioides Mart and understanding of the weed biology offers a key to improved weed management strategies such as different stages of susceptibility for weed control and this might contribute to the development of management options for this weed that has become a common weed on mown grass in Nigeria and in Ghana a weed of lawns, and gradually infesting agricultural crop fields. The objective of this study was to determine the volume of seedbank and floristic growth pattern of $G$. celosioides Mart in the southern Guinea savanna zone of Nigeria.

\section{MATERIALS AND METHODS}

The experiment was carried out at the screen house of University of Ilorin Sugar Research Institute (Lat. 8० 29'N \& 8०30'N; Long. 4० 30'E \& 4० 32'E) in the southern Guinea savanna zone of Nigeria.

\section{Experiment I}

Five seedlings of $G$. celosioides growing under natural conditions with an average height of $0.73 \mathrm{~m}$ were collected from five locations (lawn, grazing field, arable field, teak plantation and fallow field) in September, 2010, 2011 and 2012 within the University of Ilorin community. Each seedling was uprooted using cutlass and transplanted into a bowl $(13 \mathrm{~cm}$ in diameter and $6 \mathrm{~cm}$ in depth) filled with $1 \mathrm{~kg}$ of soil collected within the uprooted seedling environs and arranged in the screen house in five replications. The seedlings were watered regularly to provide enough soil moisture. These seedlings were monitored at 3 weeks intervals for 12 weeks to determine plant height, number of leaves, number of branches, number of flowers and leaf area.

\section{Experiment II}

Soil sample of $0-15 \mathrm{~cm}$ depth around each seedling was also taken using soil auger and bulked to make a composite sample. The composite soil samples were taken to the screen house, sieved using $2 \mathrm{~mm}$ sieve to remove fragments and pebbles. The sieved samples were used to estimate the volume of $G$. celosioides seedlings in the soil seed bank using direct seedling germination method. Five hundred gram of the sieved soil samples from each location were weighed out and poured inside the plastic bowls $(13 \mathrm{~cm}$ in diameter and $6 \mathrm{~cm}$ depth) and arranged on screen house benches in completely randomized design and replicated nine times. The soil samples were watered every day to provide enough moisture and stirred at three weeks interval. 
The germination of $G$. celosioides seedlings were monitored at 3, 6, 9, 12 and 15 week after establishment (WAE) using three replicates. The weight of seedlings were estimated from two replicates using destructive sampling at 3, 6, 9, 12 and 15 WAE (two bowls per sampling). Seedlings were removed from the bowls and their organs (root and shoot) were separated and then dry matter (DM) evaluation of organs were taken after drying in an oven for 24 hours at temperature of $70^{\circ} \mathrm{C}$. While emerged seedlings in the remaining five replicates were thinned to one seedling per bowl and where compared with the transplanted seedlings in experiment I.

\section{Seedbank estimation}

The number (size) of $G$. celosioides seeds in the seedbank $(Y)$ per land area $\left(\mathrm{m}^{2}\right)$ was estimated by multiplying the number of seeds in soil sample $(G)$ by the inverse ratio of the volume of soil in the auger sample to the volume of soil in $1 \mathrm{~m}^{2}$ area sampled to the depth of the auger $(15 \mathrm{~cm})$.

The ratio was computed as in Ndarubu and Fadayomi (2006):

Volume of soil from the auger sample $\left(\mathrm{V}_{1}\right)$

$V_{1}=\pi r^{2} h$, where $\pi=22 / 7, r=$ radius of the auger and $h=$ depth of sampling

$V_{1}=22 / 7 \times(3.7 \mathrm{~cm})^{2} \times 15 \mathrm{~cm}=645.2097 \mathrm{~cm}^{3}$; or $6.45 \times 10^{-4} \mathrm{~m}^{3}$

Volume of soil from $1 \mathrm{~m}^{2}$ area sampled $\left(\mathrm{V}_{2}\right)$

$V_{2}=L \times B \times H$, where $L=$ length, $B=$ breadth and $H=$ depth of sampling.

$V_{2}=100 \mathrm{~cm} \times 100 \mathrm{~cm} \times 15 \mathrm{~cm}=1.5 \times 10^{-1} \mathrm{~m}^{3}$

$Y=V_{2} / N_{1} \times G$, where $Y=$ estimated density of $G$. celosioides per $m^{2}$ to the depth of $15 \mathrm{~cm}$.

$G=$ number of emerged $G$. celosioides seedling per soil sample.

The calculated inverse ratio of the volume of soil from an auger sample to the volume of soil per $\mathrm{m}^{2}$ was 232.56 . The data of $\mathrm{G}$. celosioides density per soil samples were then extrapolated to $\mathrm{G}$. celosioides density per $\mathrm{m}^{2}$ by multiplying with 232.56 .

\section{Data analysis}

Growth and developmental parameters such as absolute growth rate (AGR), relative growth rate (RGR), leaf production rate (LPR) and rate of flowering (FR) were calculated between successive sampling periods using the formula proposed by Radford (1967) and modified by Lambers et al., (1998). Seedling growth data were square root transformed to normalize variance. The mean data obtained in experiment I were subjected to analysis of variance as a $2 \times 5$ factorial in a randomized complete block design while experiment II was analyzed using CRD procedure with the aid of Genstat Statistical Package. The treatment means were separated by using Fisher's Protected Least Significant Difference (LSD) test at $P=0.05$.

\section{Weed seedbank composition}

\section{RESULTS AND DISCUSSION}

The emergence of $G$. celosioides seedlings from soil seedbank is presented on Table 1 . The cumulative emergence from seedbank estimated was significantly affected by soil sampling location. Soil samples obtained from lawn had a significantly higher density of $G$. celosioides, (1874 seedlings $/ \mathrm{m}^{2}$ ) while fallow field had 387 seedlings $/ \mathrm{m}^{2}$ which was significantly lower than other sampling locations. The high density from lawn indicates a high level of infestation and 
returns per plant cycle and possibly poor weed management options whereas other fields had low emerged seedling compared to lawn, this gives an insight of impact of farming practices on weed establishment also shows a gradual colonization of such fields by the alien weed species. Though emerging seedling from this study gave a reasonably good estimate of the possible field emergence, they represented only a small and variable fraction of the volume of $G$. celosioides seed bank in the sampled soil. Thus, Rahman et al. (2000) reported that the asymptotic behavior of weed seedlings might be expected when soil seed bank become very large.

\section{Growth of G. celosioides seedling}

The increase in plant height and the number of branches produced at different WAE was studied (Table 2). The plant continued to increase in height from emergence to 12 WAE. The transplanted seedling had significantly taller plant compared to the germinated seedling except at $3 \mathrm{WAE}$. The differences in height could be due to the initial height of $0.73 \mathrm{~cm}$ at the time of transplanting while the similarity in height at 3WAE could be due to slow rate of growth by the transplanted seedling which might arose from shading of initial leaves resulting in reduced photosynthesis leading to poor dry matter accumulation. Ravindra et al. (2008) reported that height of Celosia argentea increased slowly during early vegetative growth but increased rapidly with age. Branching was gradual process, started at 3 WAE increased to 2 branches (mean value) at 6 WAE and stabilised to 3 branches from 9 to 12 WAE. This conformed to the results of Burkill (1984) who reported the $G$. celosioides is ascending to erect and sparsely branched.

Table 3 shows that number of leaves produced by G. celosioides at 3 WAE were 6 leaves and counted up to 30 leaves at 12 WAE. Site of collection of seedling differed significantly in number of leaves produced at 6,9 and 12 WAE. The seedling obtained from lawn had significantly higher number of leaves although similar to other location at 12 WAE except arable field. The leaf area was highest $\left(1.837 \mathrm{~cm}^{2}\right.$ plant-1) at 12 WAE and lowest $\left(0.179 \mathrm{~cm}^{2}\right.$ plant-1) at 3 WAE. Flowering commenced at 3 WAE, the plant continued to flower until to about 28 flowers at 12 WAE (Table 4).

The dry matter (DM) accumulation of the plant organs showed significant differences across the assessment period except at 9 and 12 weeks of age that similar trend was observed (Table 5). Generally, total DM production of G. celosioides was from 4.63 to $13.32 \mathrm{~g} \mathrm{plant}^{-1}$ irrespective of growth stage. At maturity (15 WAE) DM accumulated was $3.79 \mathrm{~g} \mathrm{plant}^{-1}$ in roots and $9.23 \mathrm{~g}$ plant1 in shoot. Aboveground DM increased rapidly during early vegetative growth but increased gradually with age. The rapid increase in aboveground DM during early growth was due to an absence of senescence until the plant attained physiological maturity.

Different growth and developmental indices like AGR, RGR, LPR and FR were calculated and are presented in Table 6. The maximum AGR was $0.22 \mathrm{~g} \mathrm{plant}^{-1}$ day $^{-1}$, the RGR was $0.23 \mathrm{~g} \mathrm{~g}^{-1}$ day-1 $^{-1}$ recorded between 0 to 3 weeks and 3-6 weeks, respectively. AGR and RGR tended to decline rapidly after 6 weeks while LPR increase sharply between 6 and 9 weeks and declined, FR

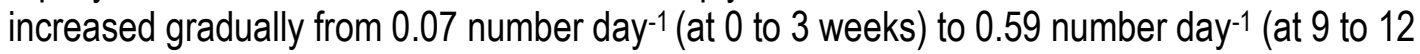


weeks) of age. Torner et al. (2000) reported similar results while studying growth of different weed species. The decreased in growth attributes makes the weed less competitive with crop and with other weeds, for resources. This did not conform to the results of Ayeni (1984) on Imperata cylindrica and Ravindra et al. (2008) on Celosia argentea.

\section{CONCLUSION}

G. celosioides seedling had a prolific growth rate, producing many leaves, sparsely branching and excessive flowers within a short period after emergence. The estimated seeds of $G$. celosioides in soil seedbank was about 885 seeds $/ \mathrm{m}^{2}$. The growing shoot increased in length as a function of plant age with a mean absolute growth rate of $0.13 \mathrm{~g} \mathrm{plant}^{-1}$ day- $^{-1}$, mean RGR of $0.07 \mathrm{~g} \mathrm{~g}^{-1}$ day $^{-1}$. The result will be valuable in aiding the prediction of likely $\mathrm{G}$. celosioides infestations in arable lands and provide a valuable input in timing of weed control.

\section{REFERENCES}

Ayeni, A. O. (1984). Observations on the vegetative growth patterns of speargrass (Imperata cylindrica (L.) Beauv.). Agriculture, Ecosystem and Environment 13: 301-307.

Bhowmik, C. P. (1997). Weed biology: Importance to weed management. Weed Science 45: 349-356.

Burkill, H. M. (1984). The useful plants of West Tropical Africa. Royal Botanical Gardens, 1: 61-62.

Fank-de-Carvalho, S. M. and Graciano-Ribeiro, D. (2005). Arquitetura, anatomia e histoquímica das folhas de Gomphrena arborescens L.f. (Amaranthaceae). Acta Botanica Brasilica 19: 379-392.

Holm, L. G., Pancho, J. V., Herberger, J. P. and Plucknett, D. L. (1979). A Geographical Atlas of World Weeds. Wiley, New York. 391 pp.

Horak, M.J. and Loughin, T.M. (2000). Growth analysis of four Amaranthus species. Weed Science 48(3): 347-355.

Lambers, H., Chapin, F. S. and Pons, T. L. (1998). Growth and allocation. In: plant physiological ecology (eds. H. Lambers, F. Chapin and T. Pans). Springer- verlag, NY, USA. 229- 351.

Marshall, E. J. P., Brown, V. K., Boatman, N. D., Lutman, P. J. W., Squire, G. R. and Ward, L. K. (2003). The role of weeds in supporting biological diversity within crop fields. Weed Research 43: 77-89.

Myers, N., Mittermeier, R.A., Mittermeier, C.G., Fonseca, G.A.B. and Kent, J. (2000). Biodiversity hotspots for conservation priorities. Nature 403: 853-858.

Ndarubu, A.A. and Fadayomi, O. (2006). Relationship between soil, weed seedbank and floristic survey estimation of weed density and species diversity on the sugar cane estate of the Nigeria sugar company Ltd, Bacita, Nigeria. Nigerian Journal of Weed Science 19:23-31.

Oladele, F. A. and Daodu, I. O. (1988). Stem Anatomical Indices for Suitability of Gomphrena celosioides Mart as a Potential Revegetation Plant. Nigerian Journal of Botany 1: 1- 4.

Onocha, P. A., Ajaiyeoba, E. O., Dosumu, O. O. and Ekundayo, O. (2005). Phytochemical screening and Biological activities of Gomphrena celosioides (C. Mart) Extracts. Journal of Nigerian Society of Experimental Biology 5(2): 61-67.

Radford, P. J. (1967). Growth analysis formulae- their use and abuse. Crop Science 7: 171-175. 
Takim et al, 2013

Radosevich, S., Holt, J.S. and Ghersa, C. (1997). Weed Ecology: Implications for vegetation management. New York: Wiley. 278-301.

Rahman, A., James, T.K., Mellsop, J.M. and Grbavac, N. (2000). Effect of cultivation methods on weed seed distribution and seedling emergence. New Zealand Plant Protection 53:28-33.

Ravindra, G.M., Sridhara, S., Girijesh, G.K. and Nanjappa, H.V. (2008). Weed biology and growth analysis of Celosia argentea L., a weed associated with groundnut and finger millet crops in southern India. Communications in Biometry and Crop Science 3 (2): 80-87.

Suzane, M. F., Misléia, R. A. G., Pedro, Í. T. S. and Sônia, N. B. (2010). Leaf surfaces of Gomphrena spp. (Amaranthaceae) from Cerrado Biome. BIOCELL 34(1): 23-35.

Torner, C., Maria, J.S., Emilio, S. and Cesar, F. (2000). A comparison of the growth patterns and the competitive ability of four annual weeds. Agriculture and Environment 20: 147-156.

Van Gessel, M. J., Schroder, J. and Westra, P. (1998). Comparative growth and development of four spurred anoda (Anoda cristata) accessions. Weed Science 46: 91-98.

Wells, M. J., Balsinhas, A. A., Joffe, H., Engelbrecht, V. M., Harding, G. and Stirton, C. H. (1986). A Catalogue of Problem Plants in Southern Africa. Memoirs of the Botanical Survey of South Africa 53:1-6.

Table 1: Mean population (no/m²) of Gomphrena celosioides seedling emerged from soil seed bank in Ilorin.

\begin{tabular}{lllllll}
\hline Location & 3WAE & 6WAE & 9WAE & 12WAE & 15WAE & TOTAL \\
\hline Arable field & 309 & 77 & 155 & 77 & 0 & 619 \\
Fallow field & 77 & 155 & 155 & 0 & 0 & 387 \\
Lawn & 637 & 464 & 387 & 232 & 155 & 1874 \\
Grazing field & 309 & 155 & 77 & 155 & 0 & 696 \\
Teak plantation & 232 & 309 & 155 & 77 & 77 & 851 \\
LSD (0.05) & NS & NS & NS & NS & NS & $207.81^{*}$ \\
Mean & 313 & 232 & 186 & 108 & 46 & 885 \\
\hline
\end{tabular}

WAE = weeks after establishment, ${ }^{*}=$ significant @ pi0.

Table 2: The Plant height $(\mathrm{cm})$ and number of branches of Gomphrena celosioides seedling at different times.

\begin{tabular}{llllllllll}
\hline Treatment & \multicolumn{3}{l}{ Seedling height $(\mathrm{cm})$} & \multicolumn{7}{c}{ Number of branches } \\
\hline Seedling (S) & OWAE & 3WAE & 6WAE & 9WAE & 12WAE & 3WAE & 6WAE & 9WAE & 12WAE \\
aGerminated & 0 & 2.00 & 5.13 & 8.42 & 8.74 & 0 & 2 & 3 & 3 \\
Transplanted & 0.73 & 2.22 & 8.03 & 11.51 & 11.93 & 1 & 3 & 4 & 4 \\
LSD (0.05) & 0.074 & NS & 0.692 & 0.853 & 0.924 & 0.185 & NS & 0.248 & 0.248 \\
Location (L) & & & & & & & & & \\
Arable field & 0.39 & 2.05 & 6.73 & 10.06 & 10.11 & 1 & 2 & 3 & 3 \\
Fallow field & 0.35 & 2.20 & 6.40 & 9.93 & 10.24 & 0 & 3 & 4 & 4 \\
Lawn & 0.33 & 2.57 & 7.21 & 10.76 & 10.29 & 1 & 3 & 4 & 4 \\
Grazing field & 0.39 & 1.89 & 6.30 & 9.07 & 9.27 & 1 & 2 & 3 & 3 \\
Teak plantation & 0.36 & 1.85 & 6.28 & 10.00 & 10.21 & 1 & 3 & 4 & 4 \\
LSD (0.05) & NS & NS & NS & NS & NS & 0.292 & NS & NS & NS \\
Mean & 0.36 & 2.11 & 6.58 & 9.97 & 10.34 & 1 & 2 & 3 & 3 \\
\hline
\end{tabular}

WAE $=$ weeks after establishment, ${ }^{*}=$ seedling germinated from soil seedbank 
Takim et al, 2013

Table 3: The Number of leaves, leaf area and flower population of Gomphrena celosioides seedling at different times.

\begin{tabular}{lllllllll}
\hline \multicolumn{1}{c}{ Treatment } & \multicolumn{3}{l}{ Number of leaves per seedling } & \multicolumn{7}{l}{ Leaf Area $\left(\mathrm{cm}^{2}\right)$} \\
\hline Seedling (S) & 3WAE & 6WAE & 9WAE & 12WAE & 3WAE & 6WAE & 9WAE & 12WAE \\
aGerminated & 7 & 12 & 18 & 30 & 0.114 & 0.239 & 0.241 & 1.705 \\
Transplanted & 5 & 10 & 17 & 29 & 0.245 & 0.447 & 0.801 & 1.968 \\
LSD (0.05) & 0.731 & NS & NS & NS & 0.021 & 0.066 & NS & NS \\
Location (L) & & & & & & & & \\
Arable field & 6 & 10 & 15 & 23 & 0.214 & 0.332 & 0.658 & 1.882 \\
Fallow field & 5 & 9 & 14 & 30 & 0.172 & 0.393 & 0.748 & 1.845 \\
Lawn & 6 & 15 & 24 & 39 & 0.264 & 0.265 & 0.505 & 1.775 \\
Grazing field & 6 & 11 & 18 & 28 & 0.114 & 0.465 & 0.437 & 1.643 \\
Teak plantation & 6 & 10 & 19 & 28 & 0.134 & 0.260 & 0.257 & 2.030 \\
LSD (0.05) & NS & 2.041 & 2.435 & 3.980 & 0.092 & NS & NS & NS \\
Mean & 6 & 11 & 18 & 30 & 0.179 & 0.343 & 0.521 & 1.837 \\
\hline
\end{tabular}

WAE = weeks after establishment, a = seedling germinated from soil seedbank

Table 4: Flower population of Gomphrena celosioides seedling at different times.

\begin{tabular}{lllll}
\hline Treatment & \multicolumn{4}{l}{ Number of flower per seedling } \\
\hline Seedling (S) & 3WAE & 6WAE & 9WAE & 12WAE \\
aGerminated & 2 & 8 & 14 & 28 \\
Transplanted & 1 & 7 & 17 & 28 \\
LSD (0.05) & NS & NS & 0.945 & NS \\
Location (L) & & & & \\
Arable field & 1 & 7 & 17 & 28 \\
Fallow field & 1 & 8 & 15 & 30 \\
Lawn & 2 & 10 & 17 & 30 \\
Grazing field & 1 & 5 & 15 & 27 \\
Teak plantation & 1 & 7 & 15 & 26 \\
LSD (0.05) & NS & NS & NS & 1.419 \\
Mean & 2 & 8 & 16 & 28 \\
\hline WAE = weeks after establishment, a= seedling germinated from soil seedbank
\end{tabular}

Table 5: Dry matter accumulation (g/plant) pattern of Gomphrena celosioides germinated from soil seedbank in llorin

\begin{tabular}{llll}
\hline Age of Seedling & Root $(\mathrm{g})$ & Shoot $(\mathrm{g})$ & Plant $(\mathrm{g})$ \\
\hline 3 weeks old & 0.24 & 4.37 & 4.63 \\
6 weeks old & 0.81 & 7.18 & 8.20 \\
9 weeks old & 3.29 & 7.23 & 10.32 \\
12 weeks old & 3.47 & 7.24 & 11.04 \\
15 weeks old & 3.79 & 9.23 & 13.32 \\
LSD $(\mathbf{0 . 0 5})$ & 0.274 & 0.495 & 1.006 \\
\hline
\end{tabular}


Takim et al, 2013

Table 6: Absolute growth rate (AGR), relative growth rate (RGR), leaf production rate (LPR) and rate of flowering (FR) of Gomphrena celosioides at different ages.

\begin{tabular}{|c|c|c|c|c|}
\hline $\begin{array}{l}\text { Age of } \\
\text { Seedling (weeks) }\end{array}$ & $\begin{array}{c}\text { AGR } \\
\text { (g plant }{ }^{-1} \text { day }^{-1}\end{array}$ & $\begin{array}{l}\text { RGR } \\
\left(\mathrm{g} \mathrm{g} \mathrm{g}^{-1} \text { day }^{-1}\right)\end{array}$ & $\begin{array}{l}\text { LPR } \\
\text { (no day-1) }\end{array}$ & $\begin{array}{l}\text { FR } \\
\text { (no day-1) }\end{array}$ \\
\hline $0-3$ & 0.22 & 0.03 & 0.29 & 0.07 \\
\hline $3-6$ & 0.17 & 0.23 & 0.24 & 0.29 \\
\hline $6-9$ & 0.10 & 0.02 & 0.33 & 0.38 \\
\hline $9-12$ & 0.03 & -0.007 & 0.24 & 0.59 \\
\hline Mean & 0.13 & 0.07 & 0.28 & 0.33 \\
\hline $\mathrm{SE} \pm$ & 0.016 & 0.004 & 0.007 & 0.012 \\
\hline
\end{tabular}

